\section{Dalea villosa 'Sandhills Satin'}

\author{
Dale T. Lindgren ${ }^{1}$ and Daniel M. Schaaf ${ }^{2}$ \\ University of Nebraska, West Central Research and Extension Center, 461 \\ West University Drive, North Platte, NE 69101-7756
}

\section{James Locklear ${ }^{3}$}

Nebraska Statewide Arboretum, University of Nebraska, Lincoln, NE 68583

Additional index words. silky prairie-clover, hairy prairie-clover, Petalostemon

Daleas (prairie-clovers) are annual or perennial, warm season legumes found from southern Canada to South America (Barneby, 1977). They are an important group of legumes in native grasslands of the Great Plains. The genus name Dalea L. is in honor of Samuel Dale, an English botanist (1659-1739). Until recently, these plants were classified in the genus Petalostemon Michx. (Weber, 1990). The prairie-clovers have potential as attractive garden ornamental plants in addition to their importance as constituents of prairies and pastures. They have uses, along with other native species, for beautification of roadsides, rest areas, parks, and recreation areas, and for soil stabilization (Salac et al., 1978). Daleas are common in the Nebraska Sandhills, an area in central Nebraska extending into South Dakota, consisting of almost $50,000 \mathrm{Km}^{2}$. It is one of the largest grass-stabilized sand dune regions in the world. The Sandhills area has many unique or special plants, such as Penstemon haydenii S. Wats. and Lithospermum caroliniense (Walter) MacMill (Bleed and Flowerday, 1989).

Dalea villosa (Nuttall) Sprengel, commonly known as silky prairie-clover, typically grows in moderately moist to dry sandy soils in disturbed sites, along right-of-ways, and in margins of sandy, wind-eroded blowouts (Farrar, 1990; Great Plains Flora Association, 1986). It has numerous, often horizontal to drooping flowering heads with pinkish-rose colored flowers. Flower spikes are solitary at ends of short branches near the top of the plant (Stubbendieck et al., 1989). Flowers are minute with five protruding yellow stamens encircling a spike up to $10 \mathrm{~cm}$ long (Farrar, 1990). Flowers mature acropetally and the fruit is a pod 2.5 to $3 \mathrm{~mm}$ long (Barneby, 1977). Plants flower from July to August, depending on location. It has one to several erect, branching stems and

Received for publication 21 Mar. 2002. Accepted for publication 8 Sept. 2002. Published as Paper No. 13616, Journal Series, Nebraska Agricultural Research Division. Research was conducted under Projects No. NEB 43-047 and NEB 43-066. We acknowledge financial support for the development of this cultivar from the Perennial Plant Association and the Nebraska Statewide Arboretum.

${ }^{1}$ Professor; to whom reprint requests should be addressed. E-mail address: dlindgren1@unl.edu

${ }^{2}$ Agriculture Research Technician.

${ }^{3}$ Director, Nebraska Statewide Arboretum. a reddish-orange taproot. A compact arching growth habit and an abundance of attractive, silvery, compound leaves give an appearance quite different from other species of the genus (Farrar, 1990). It has numerous alternate, odd-pinnately compound leaves, up to 2 to $4 \mathrm{~cm}$ long, with 11 to 25 leaflets, narrowly elliptic and 5 to $11 \mathrm{~mm}$ long (Great Plains FloraAssociation, 1986). Stems and leaves are silvery-green with short, white hairs (Farrar, 1990). Leaves are dotted with glands on the lower surface.

The species is found from Manitoba to central Texas and from western Wisconsin to eastern Colorado (Barneby, 1977).

\section{Origin}

Seed collected from a population of $D$. villosa plants in northern Lincoln County, Nebr., in 1988 was grown in field plots at the Univ. of Nebraska West Central Research and Extension Center near North Platte. The soil at the evaluation site is a Cozad silt loam (finesilty, mixed, mesic Fluventic Haplustoll), $\mathrm{pH}$ 7.6. Of the 115 seedling plants set in the field, one plant survived for 3 years while all others died. Seeds from this plant were collected, germinated, and the progeny were planted in field plots in 1992. The original plant survived through 2000. Seeds from progeny with the most uniform plant habit, foliage color, and aesthetic appeal were selected in 1994 and planted in 1995. Seeds were again harvested from selected plants with the best survival and most attractive foliage and growth habit in 1997 and planted in 1998. This was the seed source for the selected population.

\section{Performance}

In 2000 at North Platte, 59 plants of this population averaged $42.6 \mathrm{~cm}$ in height $(\mathrm{SD}=$ 7.0) and averaged 25.8 stems per plant ( $\mathrm{SD}=$ 9.51), and flowered from 20 July to 14 Aug. A comparative population obtained from North Dakota averaged $51.8 \mathrm{~cm}$ in height and 19.2 stems per plant, and flowered from 11 July to 2 Aug. 2000, 9 d earlier than the Nebraska population.

In 1997 and 1998, seed of this population was either given a cold, moist pregermination treatment for 6 weeks or no (0 week) pregermination treatment. Seeds were sown $7 \mathrm{~mm}$ deep contained in $50 \times 35 \times 9 \mathrm{~cm}$ metal flats. The medium, a peat-lite mix (Redi-Earth,
Scotts Co., Marysville, Ohio), was moistened and maintained at $0 \pm 2{ }^{\circ} \mathrm{C}$ for 6 weeks. At the end of 6 weeks, an additional set of trays (0-week treatment) was prepared in the same manner. Both treatments were placed in the greenhouse, where temperatures were maintained at a minimum of $24^{\circ} \mathrm{C}$ day $/ 12^{\circ} \mathrm{C}$ night under natural light. Treatments were replicated four times with 50 seeds per replicate. The total number of seedlings that emerged within 6 weeks were recorded.

The seed emergence study suggested that no pregermination seed treatment ( 0 weeks) significantly $(P<0.05)$ enhanced seed emergence $(36.5 \%$ emergence averaged over 2 years) for $D$. villosa, compared to the 6-week treatment $30.3 \%$ emergence averaged over 2 years). Differences for years and for year by time (weeks) were nonsignificant for seed emergence.

In 2001, individual flower heads were removed, and the number of florets per head (both with and without seed), and seeds per head were counted on 23 plants. The length of the heads averaged $53 \mathrm{~mm}(\mathrm{SD}=16.0)$, the number of florets per head averaged 137.5 $(\mathrm{SD}=48.1)$, the number of seeds per head averaged $59(\mathrm{SD}=36.8)$, and the percentage of florets per head with fully developed seeds averaged $38.5 \%(\mathrm{SD}=25.9)$. Highly significant $(P<0.01)$ positive correlations were noted between head length and number of florets per head $(r=0.96)$. Significant $(P<0.05)$ correlations were noted between head length and number of seeds per head $(r=0.43)$ and between the number of florets per head and number of seeds per head $(r=0.47)$. The percentage of florets in individual heads with seed was not significantly correlated with any of the other three traits. The number of seeds per gram averaged $559(\mathrm{SD}=8.4)$.

The name 'Sandhills Satin' was assigned to this seed-propagated line in recognition of the Nebraska Sandhills, one of its major areas of adaptation.

An important concern about D. villosa 'Sandhills Satin' is its soil requirements. It grows best on sandy-type soil, but has also performed well on the silt loam soils in the Platte Valley near North Platte. Susceptibility of seedlings to damping off disease should be noted. However, with close attention to germination and emergence conditions, damping off of seedlings can be avoided. Propagation by vegetative cuttings has not been successful thus far. Research to overcome this problem will be addressed in a future study.

\section{Availability}

This selection is being released in conjunction with the Nebraska Statewide Arboretum as a Great Plants selection and is part of the recognition of the centennial of the Univ. of Nebraska West Central Research and Extension Center, North Platte. Correspondence concerning this release should be addressed to Dale T. Lindgren, Univ. of Nebraska, West Central Research and Extension Center, 461 West University Dr., North Platte, NE 691017756. 


\section{Breeding, Cultivars, Rootstocks, \& Germplasm Resources}

\section{Literature Cited}

Barneby, R.C. 1977. Daleae imagines. Memoirs of the New York Bot. Garden 27:892.

Bleed, A. and C. Flowerday, eds. 1989. An atlas of the Sandhills. Resource Atlas No. 5. Conservation and Survey Div., Inst. of Agr. and Nat. Res. Univ. of Nebr., Lincoln.
Farrar, J. 1990. Field guide to wildflowers of Nebraska and the Great Plains. Nebr. Game and Parks Commission, Lincoln.

Great Plains Flora Association. 1986. Flora of the Great Plains. p. 439-445. Univ. Press Kansas, Lawrence.

Salac, S.S., P.N. Jensen, J.A. Dickerson and R.W. Gray, Jr. 1978. Wildflowers for Nebraska land- scapes. Univ. of Nebr. Inst. of Agr. and Natl. Res. Misc. Publ. No. 35. Lincoln.

Stubbendieck, J., J.T. Nichols and C.H. Butterfield. 1989. Nebraska range and pasture forbs and shrubs. p. 57-58. Univ. of Nebr. Coop. Ext. E.C. 89-118. Lincoln.

Weber, W.A. 1990. Colorado flora: Eastern slope, p. 189-190. Univ. Press Colo., Niwot. 